\title{
West Anglia main line upgrade - a geotechnical perspective
}

1 Vincent Nyambayo BSc (Hons), MSC, PhD, DIC, CEng, MICE Principal Geotechnical Engineer, SNCL (Atkins), London, UK

2 Naveena Chandrashekharaiah MTech, PhD, CEng, MICE Team Leader, Ground Engineering \& Tunnelling Practice, SNCL (Atkins), Bangalore, India

3 Chris Gray MEng, GMICE

Geotechnical Engineer, SNCL (Atkins), London, UK (corresponding author: christopher.gray@atkinsglobal.com)
4 Danielle Allum BSC, MSc, DIC, GMICE

Geotechnical Engineer, SNCL (Atkins), London, UK

5 Evans Koka BEng (Hons)

Design Manager, VolkerFitzpatrick, London, UK

6 Michael Asare BEng, MSc

Project Engineer, Network Rail, London, UK
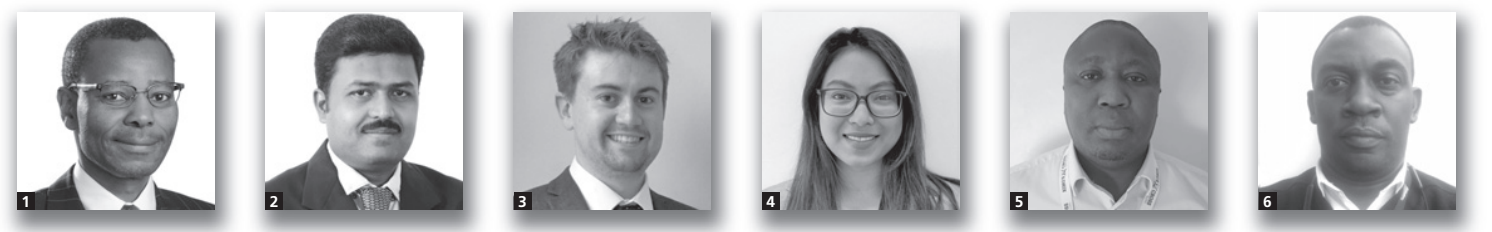

London is a megacity with a population of just under 10 million people that is increasing. Investment in major infrastructure projects is required to cope with this growth, including the upgrade of existing rail infrastructure. The West Anglia main line project in north London involves upgrading the railway network to meet the demands spawned by the regeneration of the Lea Valley hinterland, catalysed by the redevelopment of the Elizabeth Park (former site of the London 2012 Olympics). The works included upgrade of Tottenham Hale and Northumberland Park stations, and construction of a brand new Meridian Water station and other lineside infrastructure. The project will increase rail capacity, provide better internal mobility and improved links to the city on this congested West Anglia main line, as well as accommodate proposed future plans for Crossrail 2 between London and Stansted airport. The project will also unlock housing development and economic growth in the boroughs of Enfield, Haringey and Waltham Forest. This paper presents a geotechnical perspective of the project and discusses the ground conditions, design and construction of the trackbed and substructures for bridges, overhead line equipment and station upgrade works. This will leave a legacy for future designers of upgrade and extension works.

\section{Introduction}

London is a megacity with a population approaching 10 million people and is the economic powerhouse of the UK (ONS, 2019). This requires investment in infrastructure projects and housing to cope with the demands of an ever-increasing population. In north London, testament is borne to the successful legacy of the 2012 Olympic games by an increased impetus in regeneration of the Elizabeth Olympic Park and its hinterland - that is the Lea Valley and Meridian Water Park (EBC, 2019). Opportunities for employment and housing are being unlocked; this in turn is attracting larger volumes of train passengers to this part of north London.

The Lea Valley lines are two commuter lines and two branches in north-east London (shown in Figure 1), so named because they run along the Lower Lea Valley of the River Lea. They were part of the Great Eastern railway, now part of the Anglia route of Network Rail.

The line between Lea Bridge and Angel Road stations originally consisted of four tracks. Following a decline in use of the passenger railway routes, the lines were reduced to a double-track railway which comprises the current up/down Cambridge line (BRB, 1963). The line from Clapton Junction (on the Chingford line) through Tottenham Hale to Cheshunt and from Broxbourne to Bishops Stortford was electrified in 1969 and from there to Cambridge in 1987. Stratford to Coppermill junction was electrified in 1989. The power supply is $25 \mathrm{kVAC}$ overhead line.

Network Rail's London and South East route utilisation strategy published in July 2011 identified future overcrowding to be an issue on the West Anglia route, with a capacity shortfall of 1400 passengers north of Tottenham Hale/Seven Sisters in the busiest peak hour (NR, 2011).

In order to meet the challenges of anticipated passenger volumes, Network Rail committed to upgrading the West Anglia main line (WAML) between Lea Valley and Angel Road stations as one of the solutions to alleviate congestion through its framework contract. The Anglia route collaboration framework comprising Atkins, VolkerFitzpatrick and Network Rail delivered WAML, a sub-project, as part of Network Rail's $£ 170 \mathrm{~m}$ Lee Valley rail programme. 


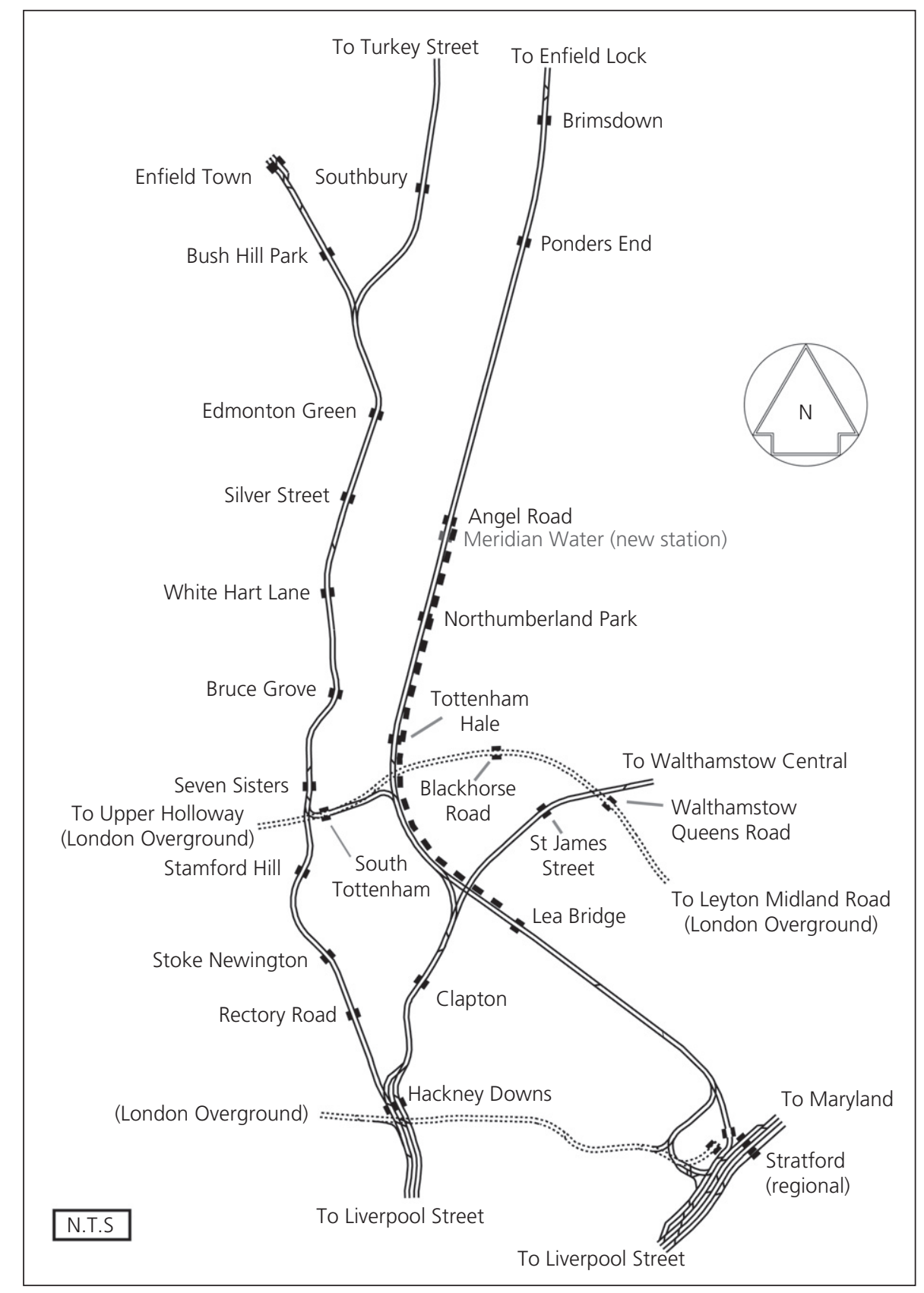

Figure 1. West Anglia main line project

The framework remit encompassed developing a single option, through to detailed design and construction.

The scheme targeted increasing the frequency of Lea Valley line services to Stratford through provision of an additional pair of tracks from Coppermill junction northwards towards Broxbourne. This would address the medium-term demand arising from industrial and residential developments in the vicinity of Lea Bridge, Tottenham Hale, Northumberland Park and Angel Road stations with a view to achieving a standard four trains per hour service between Stratford and the new Meridian Water station (which replaced Angel Road station).

Disused land which used to carry the historical third track that was decommissioned in the 1960s (BRB, 1963) was used to reinstate a third track and its associated infrastructure between Lea Bridge and Angel Road stations. Passive space was provided for a fourth track to accommodate a future Crossrail 2 extension proposed to run between Wimbledon and 
Broxbourne. The scheme (Figure 1) included the upgrade of Tottenham Hale and Northumberland Park stations, and construction of Meridian Water station.

Overall, the project will increase rail capacity, provide better internal mobility and improved links to the city on this congested West Anglia main line, as well as accommodate the proposed northern regional branch of Crossrail 2 between Tottenham Hale and Broxbourne. The WAML project was completed in 2019 and will unlock sites for housing development and economic growth in the boroughs of Enfield, Haringey and Waltham Forest.

This paper presents the design and construction of some of the significant substructure elements of the scheme and will provide a legacy of reference material for future ground engineers involved in the maintenance and design of expansion of this part of the railway - that is, Crossrail 2.

\section{Route-wide geology}

The British Geological Survey (BGS) 1:50 000 geological map, North London Sheet 256 (BGS, 2006), indicates that overall the strata sequence in the northern section of the site is characterised by made ground, overlying Enfield Silt member and occasionally alluvium, Kempton Park Gravel member, London Clay formation, Harwich formation and the Lambeth Group. In the southern section the Enfield Silt is absent but there is a greater preponderance of alluvium.

A number of ground investigations were carried out to inform the ground models and design of the various structures along the route. The trackbed investigation was carried out following the guidelines of the Network Rail standard (NR/L2/TRK/ 9039 (NR, 2011)) along the project corridor. It involved trial pits to $1.2 \mathrm{~m}$ depth with follow-on dynamic cone penetrometer testing using the Transportation Research Laboratory (TRL) hammer (TRL, 2004) at the base of the trial pit to $1 \mathrm{~m}$ depth. The trial pits were spaced at $50 \mathrm{~m}$ intervals and staggered along the wayleave.

For bridges, overhead line equipment (OLE) foundations and station extension works, the ground investigation techniques involved cable percussion rigs, dynamic sampling trackmounted rigs supplemented with cone penetrometer testing at locations where significant depths of soft soils were expected (Figure 2). Borehole depths ranged between $5 \mathrm{~m}$ and $30 \mathrm{~m}$ depending on anticipated loadings and foundation types (Eurocode 7, Part 2 (BSI, 2004b)). Associated laboratory testing was also carried out and included classification, strength and consolidation tests, in order to characterise the ground. Overall the results from the ground investigation correlated well with the geology presented in the BGS memoir (Figure 3).

The following soil descriptions describe the geological units encountered during the ground investigation. (See Table 1.)

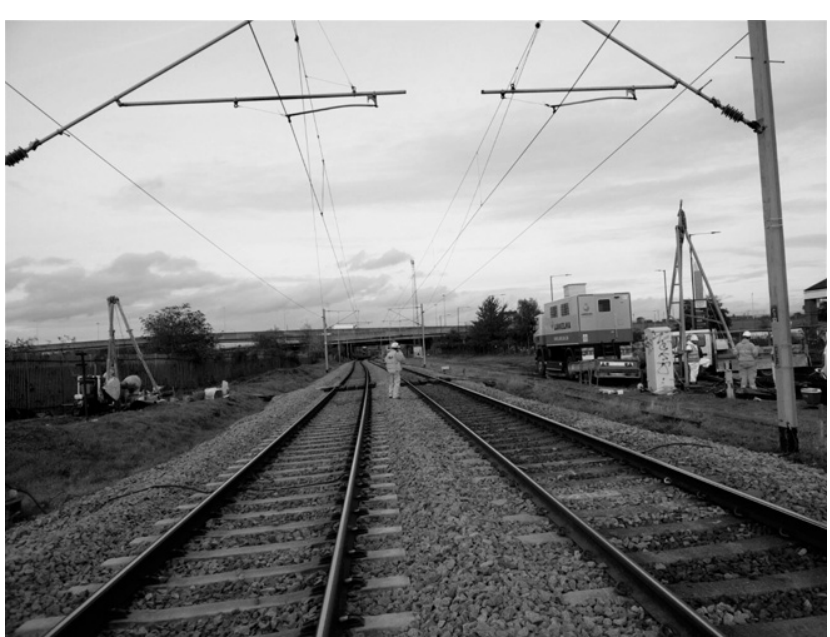

Figure 2. Ground investigation at proposed Meridian Water station during a possession

Made ground was encountered in all exploratory holes in varying thicknesses across the route. Made ground was typically described as black, dark grey, brown fine to coarse sandy gravel. The gravel was angular to sub-angular, fine to coarse granite (historical trackbed ballast) and clinker. Below the trackbed ballast (where present) the made ground was soft to stiff orange brown to brown slightly gravelly clays and silts. The gravel was of brick, concrete, flint, clinker, metal and glass.

Localised areas with alluvium were encountered in exploratory holes, described as soft black, grey, light/orange brown slightly gravelly, rare locally peaty clayey silt. The gravel was angular to sub-angular fine to coarse black flint. Slight organic odour was occasionally noted. Alluvium was also described as stiff orange brown and light grey, fine to medium sandy, locally very sandy clay.

Enfield Silt member was encountered underlying the made ground or alluvium at the northern end of the site. The Enfield Silt was generally soft to firm slightly gravelly clayey silt. The gravel was sub-angular to rounded brown flint.

Kempton Park Gravel member was encountered in all exploratory holes underlying the made ground, alluvium or Enfield Silt with thicknesses varying across the site. The Kempton Park Gravel member is the lowest river terrace deposit in the Lee Valley and typically comprised medium dense to dense and occasionally becoming loose with depth, grey, brown slightly silty, slightly fine to coarse sandy gravel. On occasion it was encountered as slightly clayey gravel. The gravel was angular to well rounded, fine to coarse flint, chert and quartz. Rare coarse sand sized shell fragments were observed in some boreholes.

London Clay formation was encountered underlying the Kempton Park Gravel member across the route in the deeper 


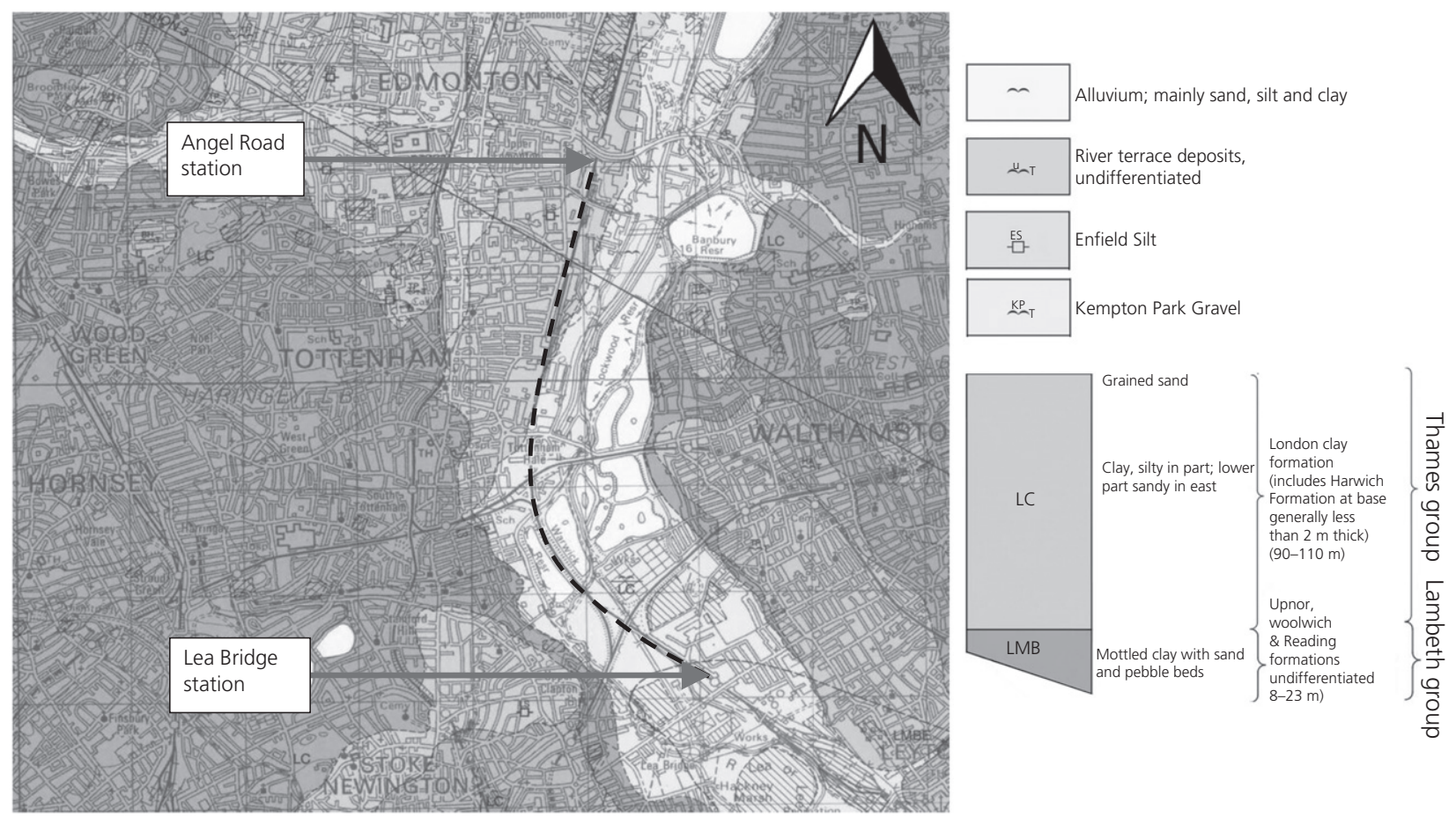

Figure 3. Geological map and strata key (BGS Extract Sheet 256). Contains British Geological Survey materials ( ) UKRI (2006). Contains topographical data (c) Crown copyright and database rights (2006) Ordnance Survey 100021290

Table 1. Encountered geological summary along the WAML route

\begin{tabular}{|c|c|c|c|}
\hline Epoch & Stratum & Typical description & Extent \\
\hline Not applicable & Made ground & $\begin{array}{l}\text { Varied from sandy gravel to soft to stiff slightly gravelly clays } \\
\text { and silts }\end{array}$ & $\begin{array}{l}\text { Present along entire length of } \\
\text { the scheme }\end{array}$ \\
\hline \multirow[t]{2}{*}{ Holocene } & Alluvium & $\begin{array}{l}\text { Soft to firm normally consolidated, compressible silty clay, } \\
\text { but can contain layers of silt, sand, peat and basal gravel }\end{array}$ & Present to the south of the site \\
\hline & Enfield Silt member & Varies from silt to clay & Present to the north of the site \\
\hline Pleistocene & $\begin{array}{l}\text { Kempton Park Gravel } \\
\text { member/river terrace } \\
\text { deposits }\end{array}$ & Sand and gravel, locally with lenses of silt, clay or peat & $\begin{array}{l}\text { Present across the scheme both } \\
\text { in historic and project } \\
\text { boreholes }\end{array}$ \\
\hline \multirow[t]{2}{*}{ Eocene } & London Clay & Silty clay, fine sandy clay at base of stratum & $\begin{array}{l}\text { Present along entire length of } \\
\text { the scheme }\end{array}$ \\
\hline & Harwich formation & $\begin{array}{l}\text { Glauconitic silty or sandy clays, silts and fine- to } \\
\text { coarse-grained glauconitic sands, some gravelly, varying to } \\
\text { flint gravel beds }\end{array}$ & $\begin{array}{l}\text { Present along entire length of } \\
\text { the scheme }\end{array}$ \\
\hline
\end{tabular}

exploratory holes. The weathered London Clay formation was firm to stiff brown grey clay. The unweathered London Clay formation was stiff to very stiff, thinly laminated, fissured dark bluish grey, slightly sandy silty clay. The sand was fine and fissures were closely spaced sub-horizontally and sub-vertically.

The Harwich formation was encountered underlying the London Clay formation from 10.20 to $13.00 \mathrm{~m}$ below ground level (bgl) with a thickness of between 0.5 and $2.5 \mathrm{~m}$ at the location of the new Meridian Water station (north end of the route). The Harwich formation was dark grey locally clayey gravelly sand
Significant contaminated ground was encountered during the ground investigation. Hydrocarbons were found in the Kempton Park Gravel from Northumberland Park station and became heavier/more concentrated moving towards the northern end of the site. The contaminated ground was associated with the historical gas works (Edmonton gas works) at the site of Meridian Water housing development which lies south of Meridian Water station. Owing to the presence of the contaminated material, piling risk assessments were undertaken for the OLE and Meridian Water station works to ensure the risk of creating a pathway from the Kempton Park Gravels to the underlying aquifer below the impermeable London Clay was 
managed during the construction works and all additional risks associated with the piling works were captured.

The presence of the hydrocarbons and high groundwater level in the Kempton Park Gravel member also drove the foundation solution, as the difficulties in handling, removing and disposing of contaminated material introduced sustainability aspects for the project (economic, environment and social) which had to be considered during optioneering in order to arrive at the optimal solutions.

\section{Trackbed}

In accordance with project requirements, the train speeds from Coppermill junction to Tottenham Hale station will attain maximum speeds of $60 \mathrm{mile} / \mathrm{h}$ which designates a category 3 track, while northwards of Tottenham Hale station maximum speeds of up to $100 \mathrm{mile} / \mathrm{h}$ had to be designed for, which equates to a track category 1 as defined in the Network Rail standard (NR/SP/TRK/9039 (NR, 2005)). The track categories dictated the design of the trackbed treatment types in order to achieve the relevant minimum stiffnesses and ballast depths, taking account of the nature of the formation materials. Category 3 track category required $200 \mathrm{~mm}$ depth of ballast beneath base of sleeper level, whereas category 1 track required an equivalent $300 \mathrm{~mm}$ depth of ballast. As the upgrade to the WAML lines applied to an existing trackbed with no reinforcement, a dynamic sleeper support stiffness of $60 \mathrm{kN} / \mathrm{mm}$ per sleeper end was used in the design as defined in the Network Rail standard (NR/SP/TRK/9039 (NR, 2005)).

The trackbed treatment was based on an assessment of the type and condition of soils encountered at subgrade level, and the specified formation material which is required to comply with filtration and stiffness criteria. This required the granular and cohesive subgrades to have different designs (Figures 4 and 5). Underbridges also required different treatments to account for transitions in stiffness along the route caused by the structures, as described below. Material type 6F5 or 6F2 in accordance with the Specification for Highway Works, Series 600 (HA, 2016) was specified as standard capping material. In the event that soft spots were encountered, it was specified that a further $600 \mathrm{~mm}$ of material be excavated and replaced with suitable capping material.

The presence of underbridges and large-diameter culverts with shallow depth cover presented hard spots within the trackbed which required transitions to be incorporated, in order to achieve gradual reduction in the trackbed stiffness as well as minimise differential settlement. Poorly designed transitions attract high maintenance costs and can also potentially compromise the track gauge, thereby presenting a derailment hazard. Trackbed transitions were designed to be incorporated on either side of the underbridges in order to achieve a smooth/gradual transition in trackbed stiffness. Figure 6 depicts the transition type adopted for underbridges and largediameter culverts at shallow depth.

\section{Lea River underbridge (BGK1393)}

\subsection{Background}

Railway routes in Britain are identified using a systematic line-referencing methodology (railway codes (RC, 2019)). Along the Bethnal Green to Kings Lynn line (BGK) the previously redundant BGK1393 - River Lea underbridge was a

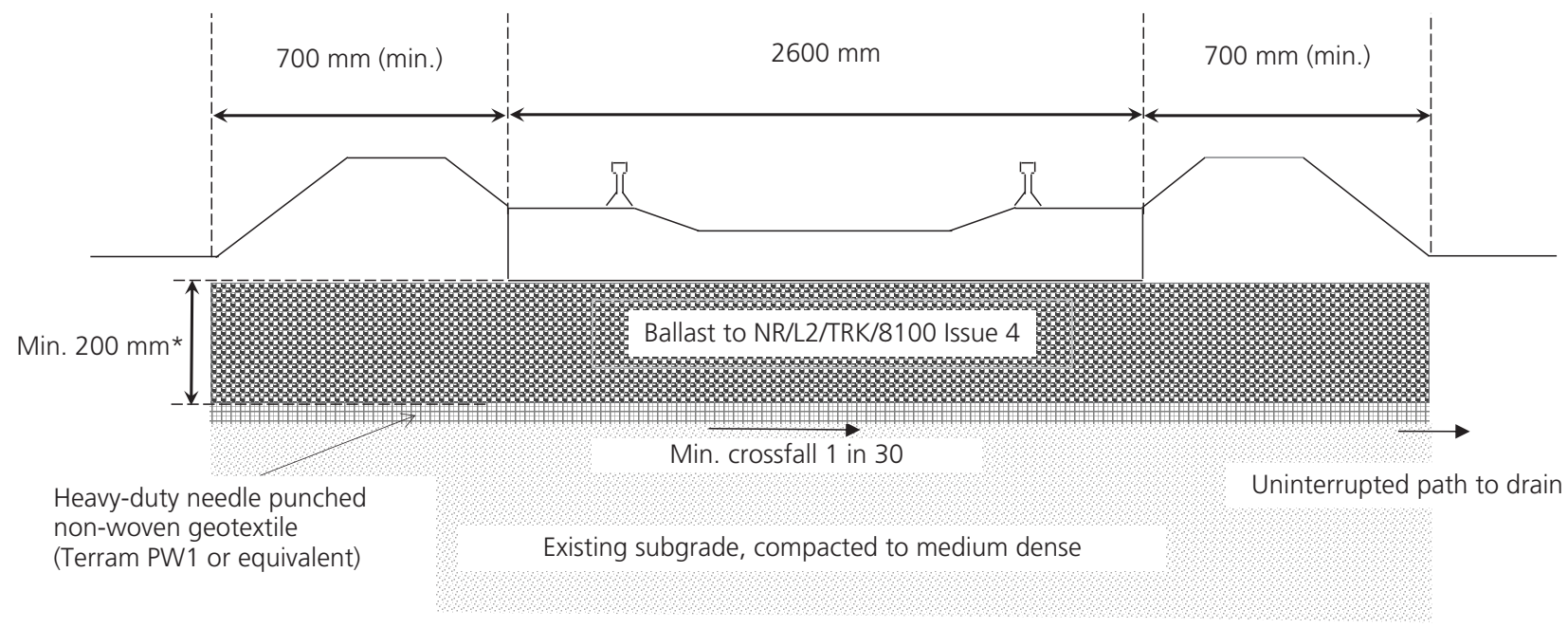

*Track category 3 - minimum $200 \mathrm{~mm}$ ballast
Track category 1 - minimum $300 \mathrm{~mm}$ ballast

Figure 4. Granular subgrade trackbed treatment (cross-section) 


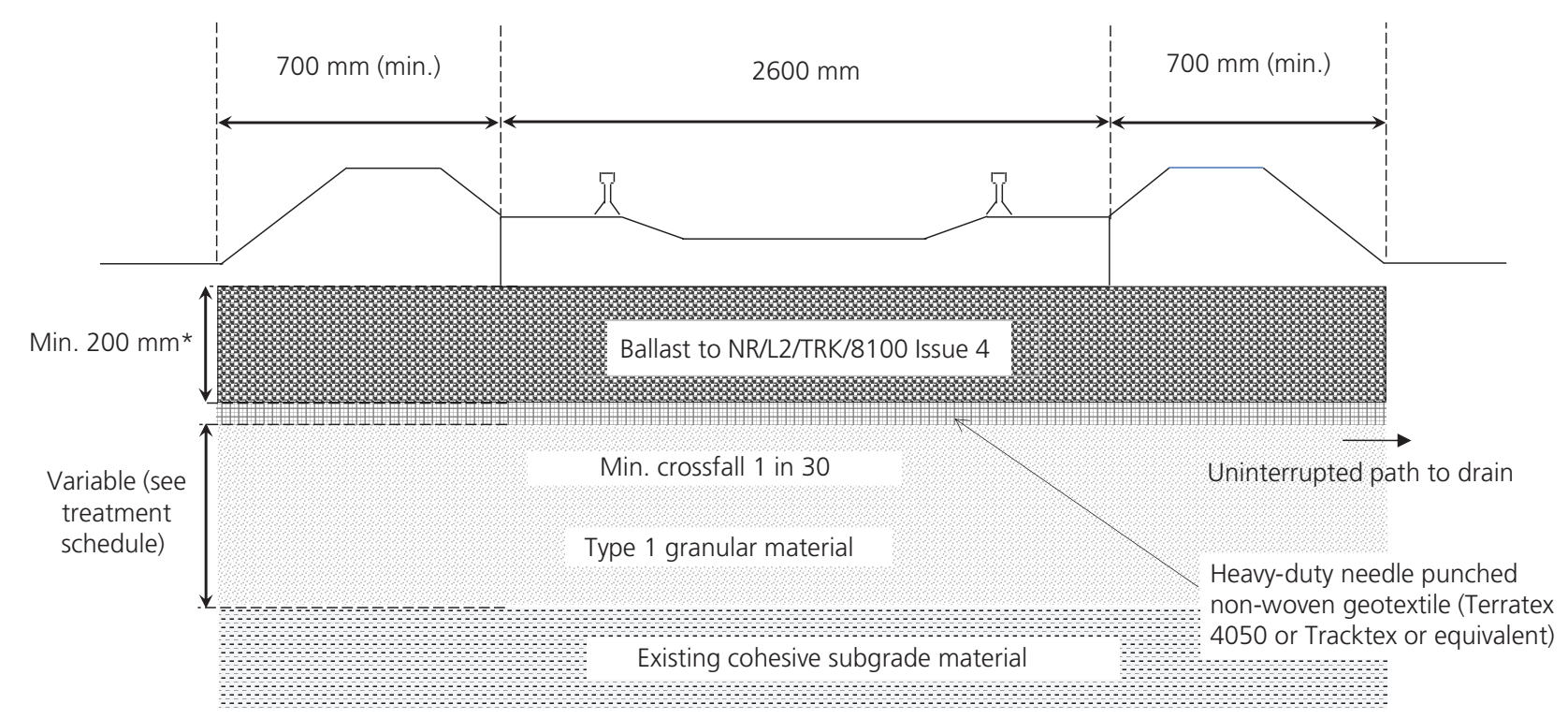

*Track category 3 - minimum 200 mm ballast

Track category 1 - minimum 300 mm ballast

Figure 5. Cohesive subgrade trackbed treatment (cross-section)

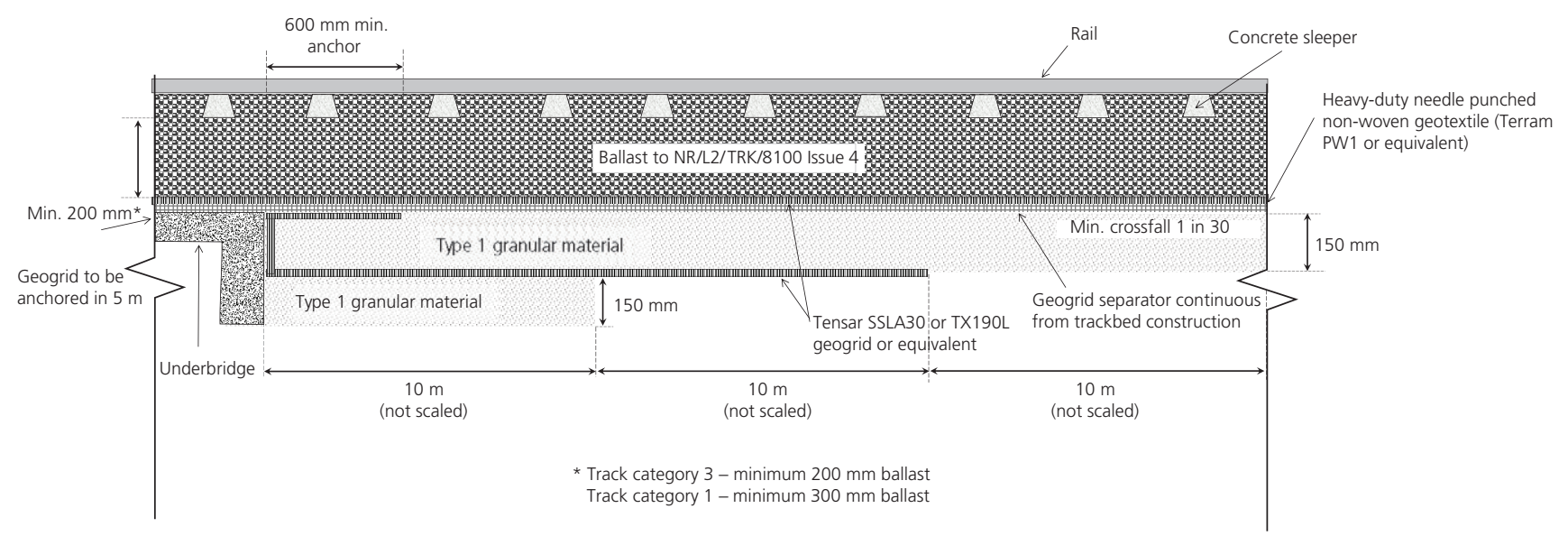

Figure 6. Trackbed transition to underbridge (elevation)

skewed $\left(26^{\circ}\right)$ three-span bridge, crossing a footpath and the River Lea (Figure 7). The main deck superstructure spanning the river comprised two riveted main girders supporting cross girders, which in turn supported the rail bearers. The two approach spans to the south were also of simply supported construction, each with three riveted metal plate girders supporting transversely laid steel troughing, which formed the decking.

At stage 4 of Network Rail's governance for railway investment projects (GRIP) business process (NR/L2/INI/P3M/101 (NR, 2017)), where a single option is developed, a value-for-money study (VfM3) was undertaken to identify where savings could be made and eliminate any unnecessary cost. It was determined that the derelict bridge could not be refurbished and reused, and nor were its foundations reusable to support the new bridge superstructure. This decision was partly driven by the inconclusive results of coring investigations to confirm the full foundation geometry. Other risks included any solution that necessitated significant temporary works and/or excavation within the river channel, as this would require secretary of state approval since this waterway is owned by the Crown Estate. This would involve a long approval process and potentially jeopardise the delivery programme. A complete 
Transport

Volume 173 Issue 4
West Anglia main line upgrade - a

geotechnical perspective

Nyambayo, Chandrashekharaiah, Gray et al.

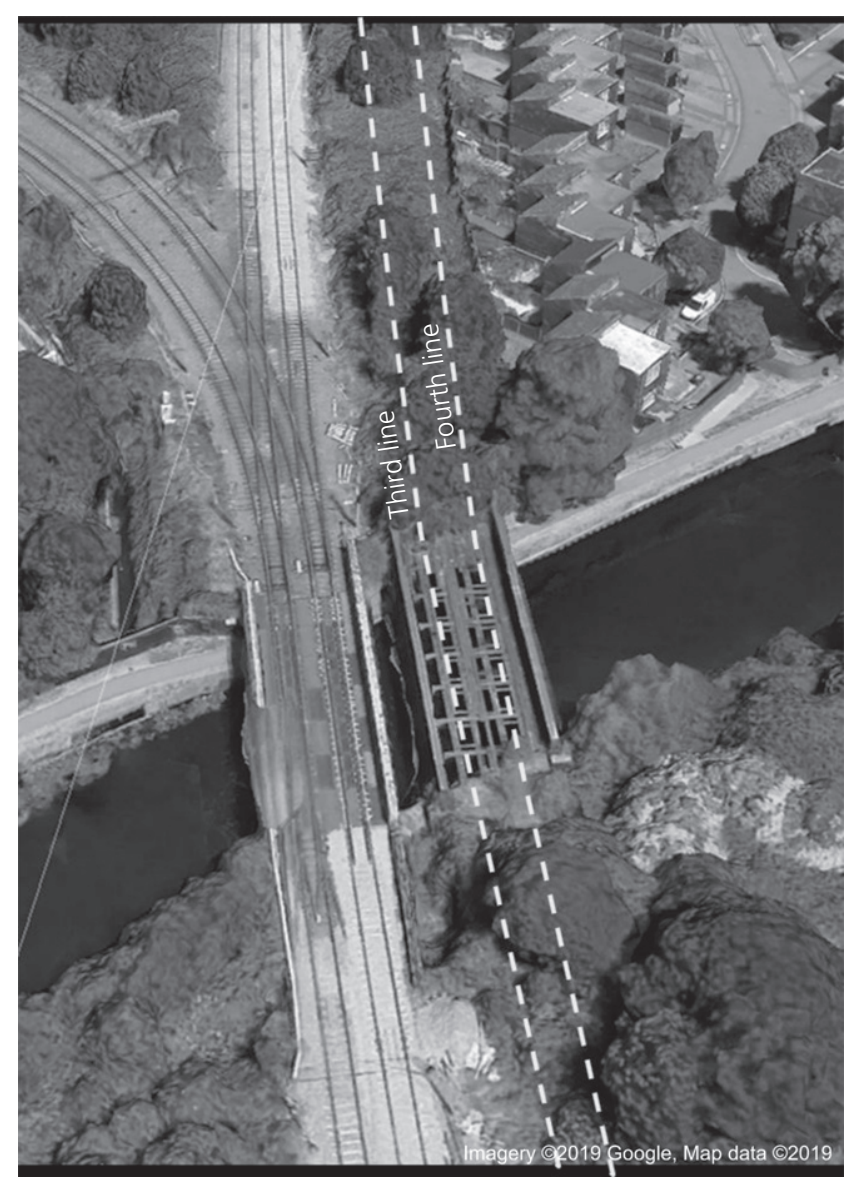

Figure 7. Location of new underbridge BGK1393 at River Lea

reconstruction of the bridge was thus proposed spanning over and beyond the existing bridge supports and supported on new abutments on piled foundations (Figure 8).

The new superstructure is a $39 \mathrm{~m}$ skew span, twin-track steel half-through bridge with a filler beam floor. Although the deck is based on a standard Network Rail 'E-type' design, this structure is a bespoke design, as the span is greater than that allowed for the standard design. The substructure at each river bank comprises a reinforced concrete (RC) abutment and wingwalls on an RC pile cap with bored, cast in situ RC piles. The original abutments at the river banks were retained to provide scour protection to the new bridge abutments.

\subsection{Ground conditions}

A site-specific ground investigation was undertaken at the location of the two proposed pile caps involving cable percussion boreholes to $30 \mathrm{~m}$ depth, cone penetrometer testing and associated laboratory testing to characterise the ground. The natural materials underlying the made ground associated with the fill of the historical approach embankments are summarised sequentially below.

Alluvium was encountered in all the boreholes, between $2.1 \mathrm{~m}$ and $6.6 \mathrm{~m} \mathrm{bgl}$, with a thickness ranging between $0.55 \mathrm{~m}$ and $2.7 \mathrm{~m}$. The alluvium was described as soft to firm sandy, gravelly clay, with pockets and lenses of soft peaty silt. The gravel was angular to sub-rounded.

River terrace deposits were encountered underlying the alluvium, ranging in thickness between $0.4 \mathrm{~m}$ and $3.9 \mathrm{~m}$. The river terrace deposits were described as medium dense to dense, light brown or brown, sandy gravel or gravelly sand. The sands were fine to coarse grained while the gravels were fine to coarse, sub-rounded to sub-angular flint, with occasional cobble sized flint.

London Clay formation was encountered underlying the terrace gravels, with minimum thicknesses of $16.5 \mathrm{~m}$ and $17.9 \mathrm{~m}$ proven in the boreholes. The London Clay formation was described as stiff to very stiff thinly laminated, fissured dark grey clay. At a depth of $23 \mathrm{~m} \mathrm{bgl}$ the London Clay was described as very stiff to hard laminated blueish grey mottled light brown slightly sandy clay. Figure 9 depicts the geology at

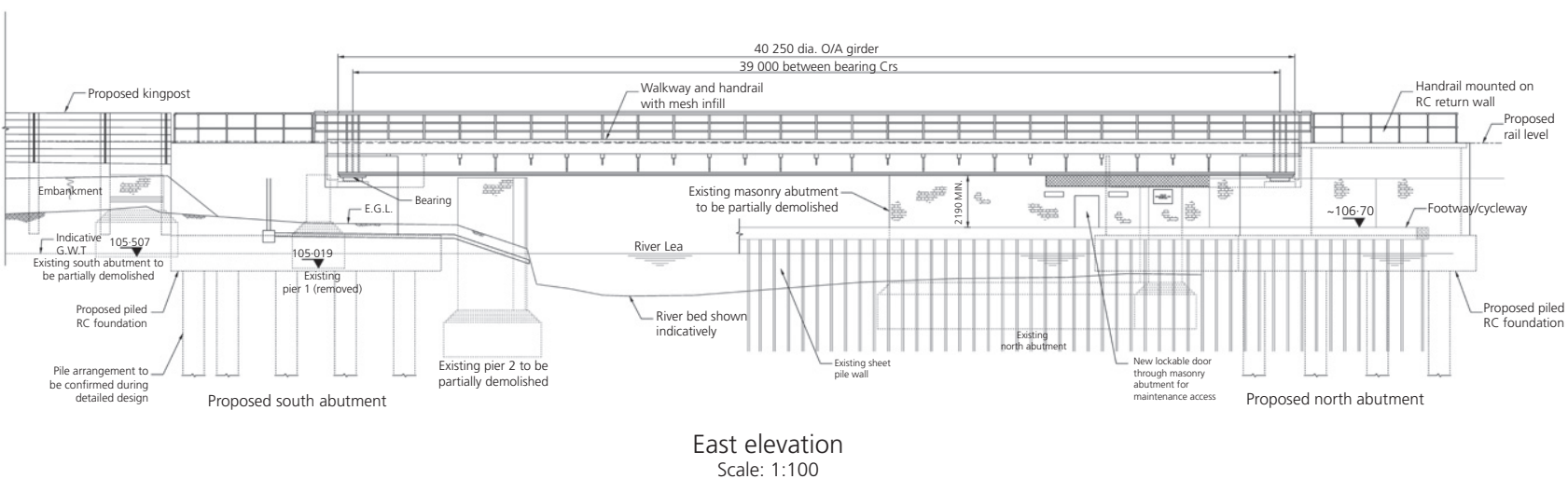

Figure 8. BGK1393 underbridge east elevation 

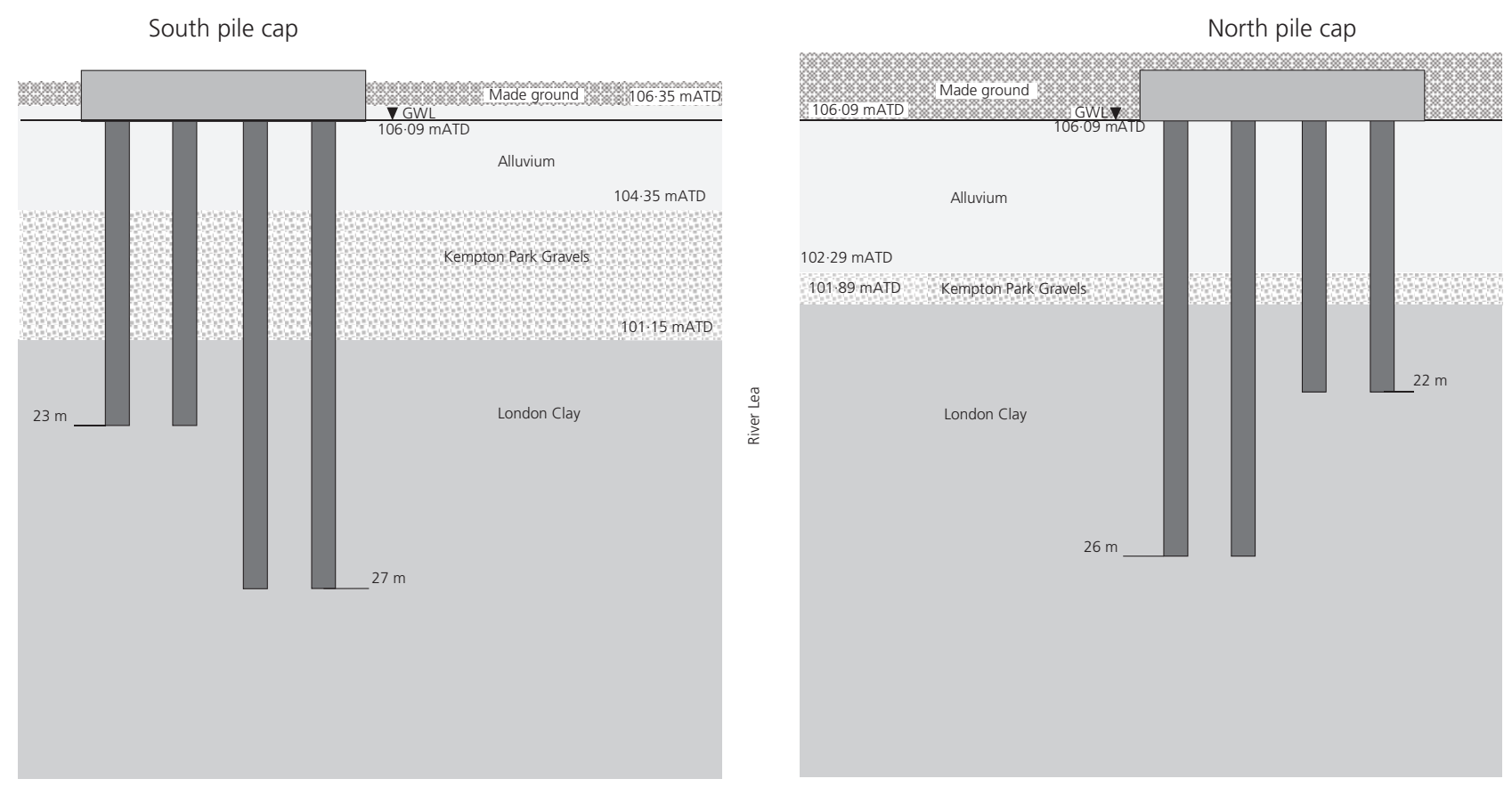

Figure 9. Schematic representation of ground model and design pile lengths (ATD, above tunnel datum)

the two bridge abutments, while Table 2 presents a summary of the soil parameters assumed in the design.

Groundwater was encountered in the alluvium and river terrace deposits at depths ranging between $3.0 \mathrm{~m}$ and $5.5 \mathrm{~m}$ bgl where the groundwater was noted to rise at depths ranging between $1.6 \mathrm{~m}$ and $3.6 \mathrm{~m} \mathrm{bgl}$ to approximate water levels in the Lea River. The geology and groundwater levels had to be specially considered in the construction of the piles. The presence of the alluvium had significant impact on the pile design and pile lengths as these weak deposits were present in the upper sections of the piles, where maximum lateral loading effects are inflicted. Furthermore, during construction, hard layers (cementitious nodules) identified in the boreholes below $23 \mathrm{~m} \mathrm{bgl} \mathrm{significantly} \mathrm{impacted} \mathrm{the} \mathrm{piling} \mathrm{operations,} \mathrm{as} \mathrm{dis-}$ cussed in Section 4.3.

\subsection{Foundation design and construction}

An iterative approach was employed using Piglet software (Randolph, 1977) to compute the pile loads and deflections in order to derive spring stiffnesses to be used for the superstructure design using Lusas software. The overall aim was to achieve convergence in pile head deflections between the geotechnical and structural models, thus increasing reliability and confidence in the design of the structure, particularly for bending and shear design capacities of the piles.

The piles were designed to meet the following placement criteria

- total vertical settlement $\leq 25 \mathrm{~mm}$ (BSI, 2004a, 2004b)

- total vertical differential settlement $\leq 5 \mathrm{~mm}$ (BSI, 2004a, 2004b)

- pile group maximum horizontal deflections $\leq 30 \mathrm{~mm}$ (BSI, 2003).

In the Piglet model, the pile cap was considered to be rigid and non-linear analysis was invoked to allow redistribution of the loads within each pile group, thereby achieving efficiencies in pile utilisation. The presence of the relatively thick layer of soft alluvium dominated the response of the pile

Table 2. Characteristic geotechnical parameters for BGK 1393 piled foundations design

\begin{tabular}{|c|c|c|c|c|c|c|c|}
\hline \multirow[b]{2}{*}{ Stratum } & \multicolumn{2}{|c|}{ Thickness: m } & \multirow{2}{*}{$\begin{array}{l}\text { Bulk } \\
\text { density, } \gamma: \\
\mathrm{kN} / \mathrm{m}^{3}\end{array}$} & \multirow{2}{*}{$\begin{array}{l}\text { Effective angle of } \\
\text { shearing } \\
\text { resistance, } \phi^{\prime}: \text { deg }\end{array}$} & \multirow{2}{*}{$\begin{array}{c}\text { Effective } \\
\text { cohesion, } \\
c^{\prime}: \mathrm{kPa}\end{array}$} & \multirow{2}{*}{$\begin{array}{l}\text { Undrained shear } \\
\text { strength, } c_{u}: \\
\text { kPa }\end{array}$} & \multirow{2}{*}{$\begin{array}{c}\text { Drained Young's } \\
\text { modulus, } E^{\prime}: \\
\text { MPa }\end{array}$} \\
\hline & South & North & & & & & \\
\hline Alluvium & 1.9 & $3 \cdot 8$ & 17 & 20 & 0 & 20 & 4 \\
\hline Kempton Park Gravel member & $3 \cdot 2$ & 0.4 & 19 & 36 & 0 & - & 16 \\
\hline London Clay formation & $>10$ & $>10$ & 20 & 24 & $1^{a}$ & $50+8 z^{b}$ & $12 \cdot 5+2 z^{b}$ \\
\hline
\end{tabular}

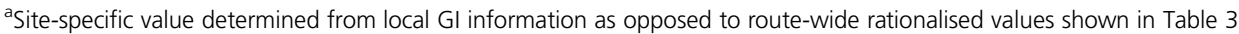

${ }^{b} z$ is measured from the top of the stratum 
group, which resulted in relatively longer piles than would have otherwise been achieved if the alluvium had not been present, as soft alluvium has low strength and low stiffness and thus provides only modest resistance to lateral loading.

Owing to the constrained access and time criticality of the programme, it was deemed that the benefit-cost ratio of either constructing temporary works to remove the alluvium or preloading were too low to justify these options. The presence of the adjacent Lea River with relatively high groundwater levels also presented significant challenges to both options, as high groundwater would increase the risk of collapse of temporary excavations, while for a pre-loading option it would impede dissipation of pore water pressures.

Nonetheless, noting that the front piles were the most laden, as this was where the bridge bearings were located, it was evident that the rear piles could be significantly curtailed in length, thereby achieving efficiencies in the overall pile design. In order to rationalise the pile lengths as well as minimise the risks of site construction errors it was decided to limit the design pile lengths to two in each pile cap, as indicated in Figure 9.

\subsection{Foundation construction}

During construction of the bridge foundations, some challenges were encountered on site which led to deviations from the designed pile lengths. Hard ground conditions associated with the presence of a significant band of claystone nodules within the London Clay significantly impacted the piling works and required dynamic modifications in order to accommodate construction constraints. The time required to chisel out the hard claystone band coupled with the risk of pile bore softening as a result of high groundwater dictated that some of the piles be prematurely terminated in order to not compromise friction resistance of the piles due to softening. Recovery measures involving longer piles were then invoked during installation of later piles in order to compensate for the loss in pile capacity of previously installed piles that had been prematurely terminated due to necessity. This therefore required the pile group to be reassessed during construction in order to determine the revised pile lengths of the piles not yet constructed and ensure foundation adequacy. This approach enabled both the design requirements and overall construction programme to be achieved. The 'asbuilt' pile lengths for the bridge are summarised in Figure 10. Figure 11 shows the removal of the original bridge deck and Figure 12 depicts the construction of the northern abutment.

\section{Ferry lane underbridge BGK1395A}

U/B 1395A is a new bridge that carries the proposed track over an existing 36 in. (914 $\mathrm{mm})$ cast-iron water main, which is located underneath the existing Ferry Lane overbridge, passing between the existing bridge foundations. Although the bridge

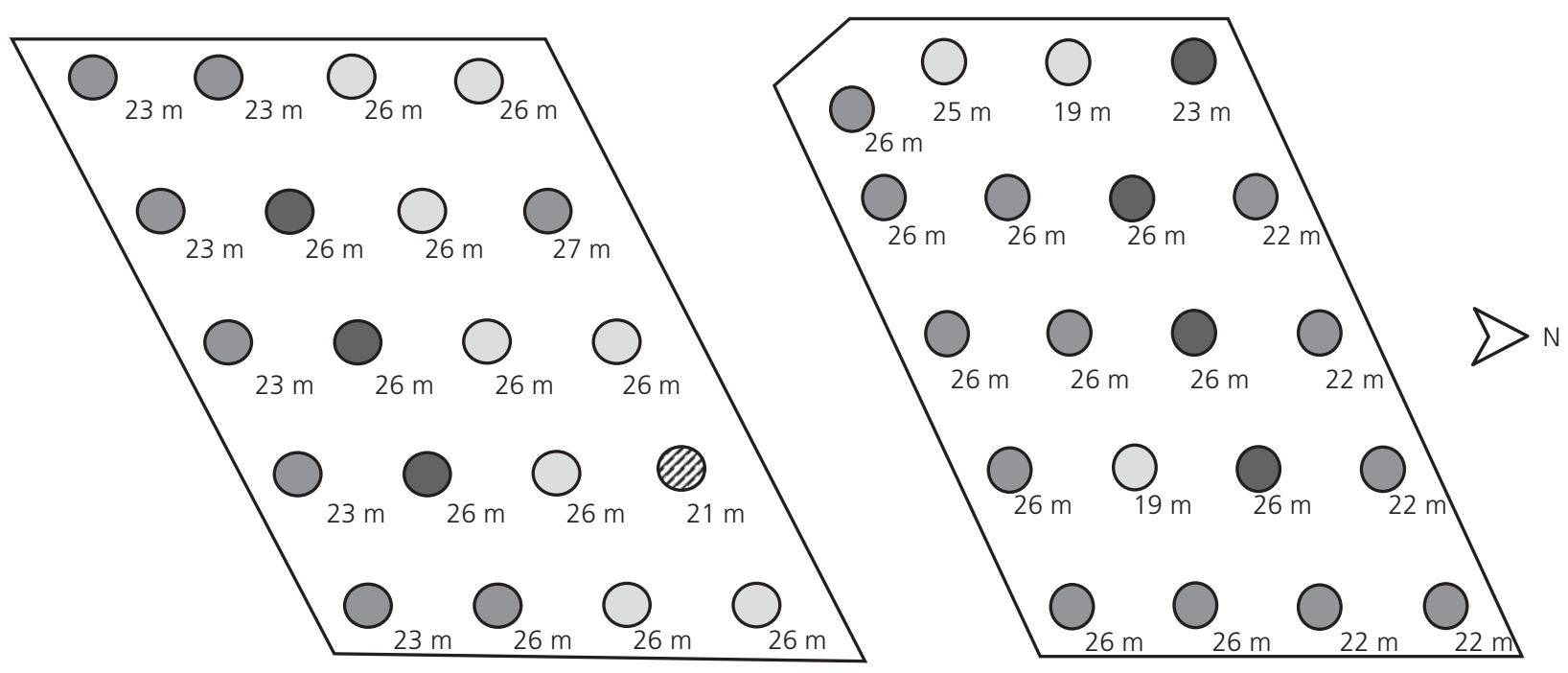

Pile installed as per designed length

Pile shorter than designed length

Pile longer than designed length

Auger lost in pile at $21 \mathrm{~m} \mathrm{bgl}$, subcontractor unable to retrieve, decision was made to install reinforcement and concrete 
West Anglia main line upgrade - a

geotechnical perspective

Nyambayo, Chandrashekharaiah, Gray et al.

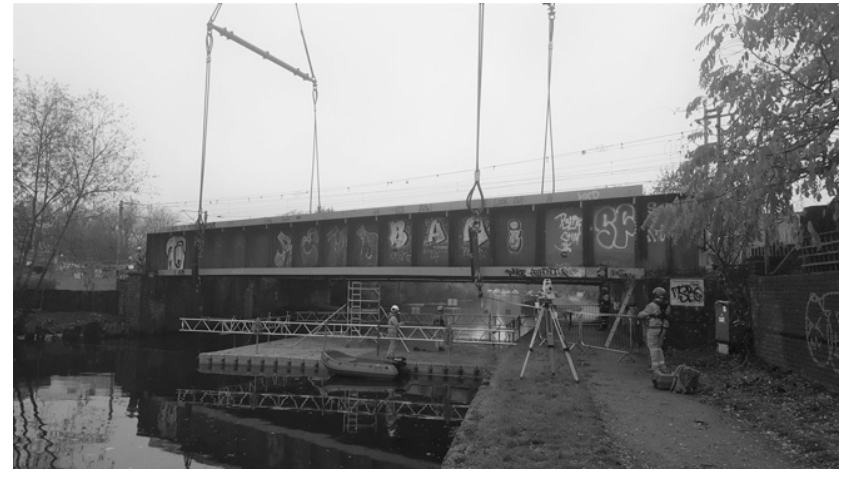

Figure 11. Removal of old bridge (also shows the river and riverside abutments to be retained for scour protection), looking west

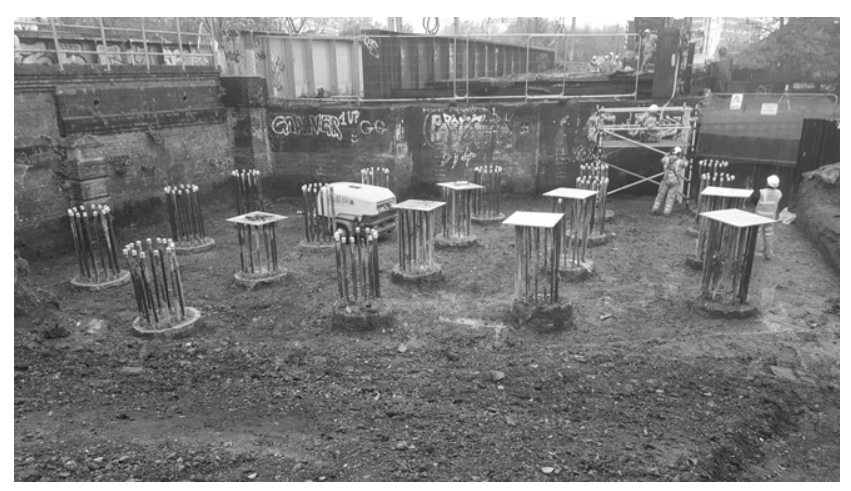

Figure 12. Piles on southern abutment (and remnants of demolished brick pier), looking north is reasonably small in scale, it presented significant design and construction challenges (Figure 13). In order to achieve the necessary OLE clearances, the track alignment over the water main is approximately $500 \mathrm{~mm}$ lower than the adjacent existing lines, and consequently there is very limited construction depth available to achieve the required clearance to the water main. Construction challenges included restricted headroom under the existing overbridge, high groundwater levels and limited clearance to the existing bridge pier. Another challenge for this design resulted from the Victoria line southbound tunnel, which is located at relatively shallow depth underneath the new underbridge. Several options were considered to support the track, details of which are given in the paper by Nyambayo et al. (2019).

The solution implemented was a $3.5 \mathrm{~m}$ span steel deck supported on RC pile caps and $300 \mathrm{~mm}$ dia. bored $\mathrm{RC}$ piles. The main span approach comprised RC track slabs also supported on $300 \mathrm{~mm}$ bored RC piles (Figure 14). The steel deck comprised a $100 \mathrm{~mm}$ steel plate and a $100 \mathrm{~mm}$ doubler plate with cut-outs to accommodate the pipe collar. Both the steel deck and track slab support Pandrol Viper rail fixings (Figures 15-17).

A comprehensive potential damage assessment was carried out to demonstrate that the effect of the proposed works on the adjacent water main, bridge piers and London Underground (LU) tunnel was acceptable. This required complex finiteelement analysis to predict the movements of the existing assets and determine additional loadings on the tunnel lining (Nyambayo et al., 2019). The assessment of the water main indicated that joint pull-out, rotation and increases in tensile

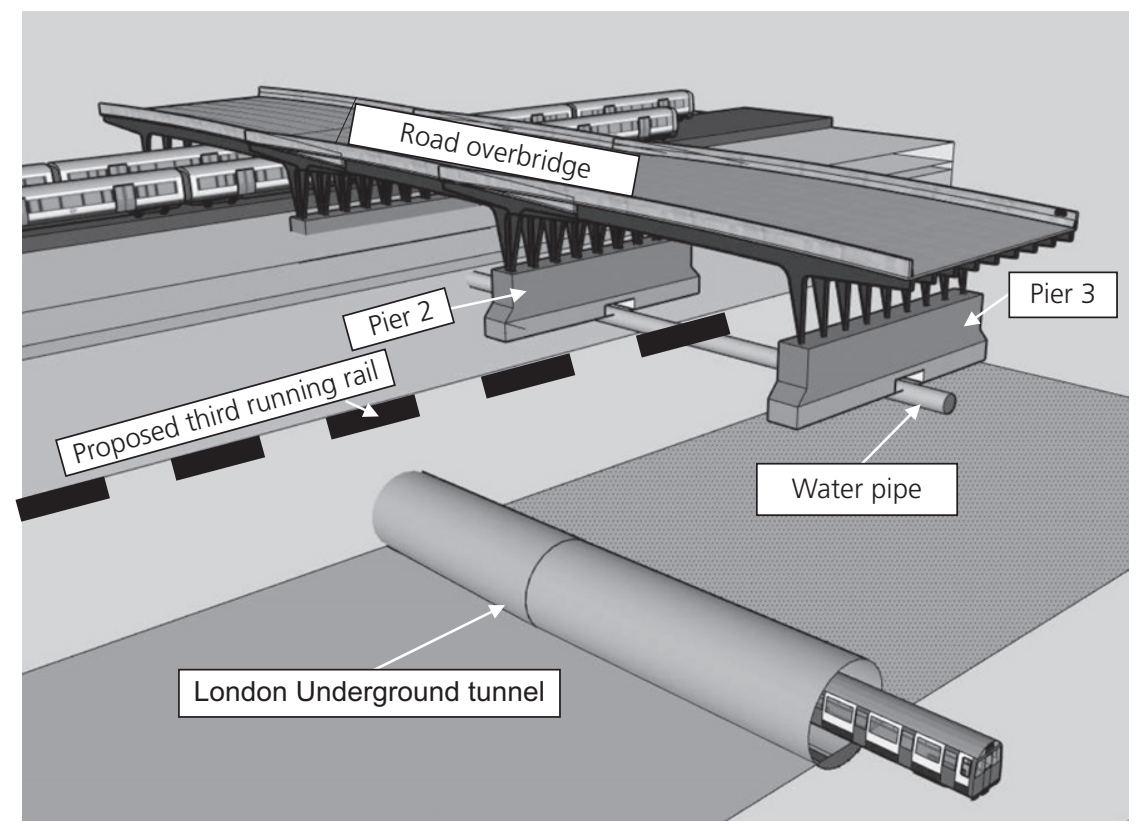

Figure 13. 3D schematic representation of the design constraints (Nyambayo et al., 2019) 
Transport

Volume 173 Issue 4
West Anglia main line upgrade - a

geotechnical perspective

Nyambayo, Chandrashekharaiah, Gray et al.

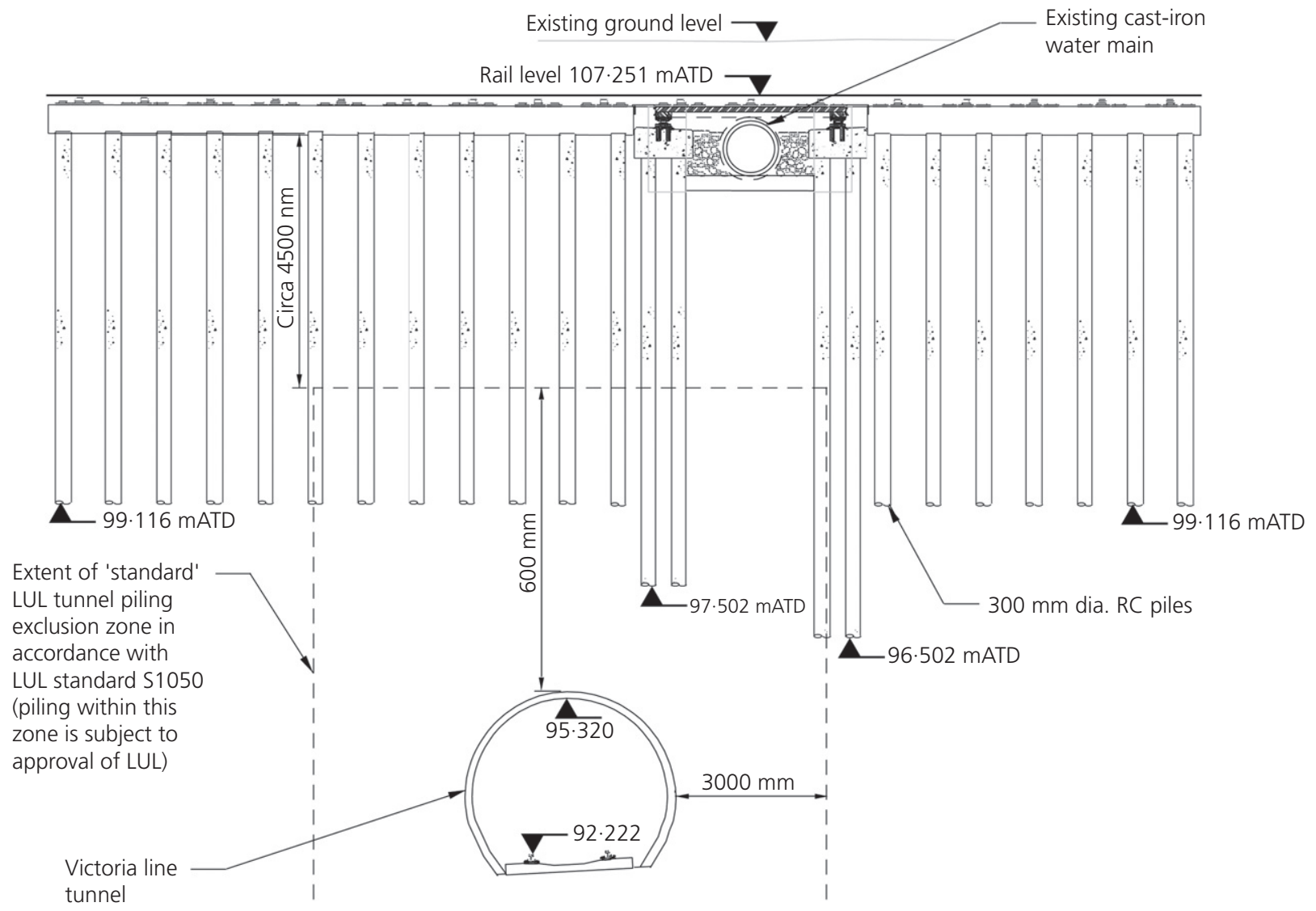

Figure 14. U/B 1395A - along track section (mATD, metres above tunnel datum; LUL, London Underground Ltd)

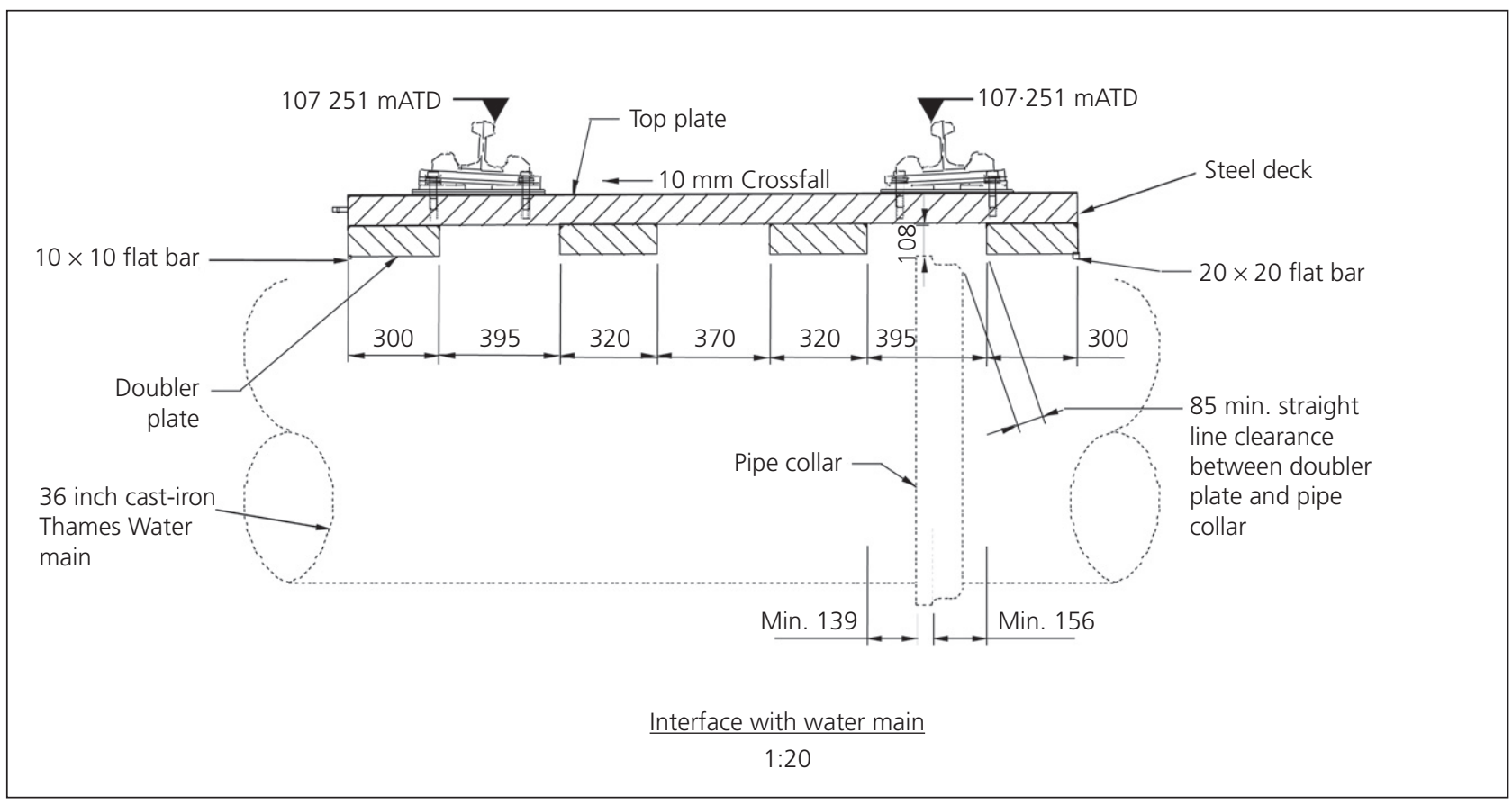

Figure 15. U/B 1395A - cross-section of steel deck interface with water main 
West Anglia main line upgrade - a

geotechnical perspective

Nyambayo, Chandrashekharaiah, Gray et al.

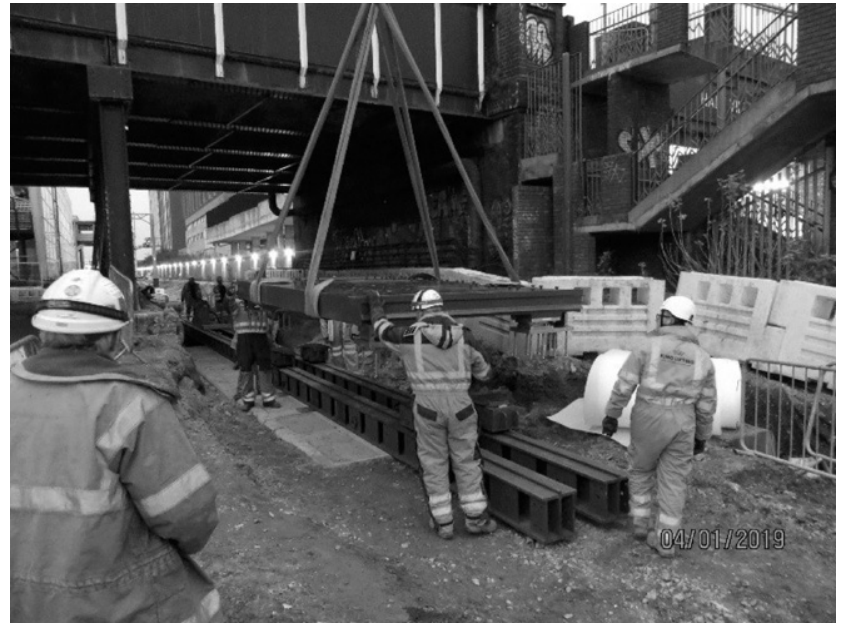

Figure 16. U/B 1395A - installation of steel deck using skid beams looking north

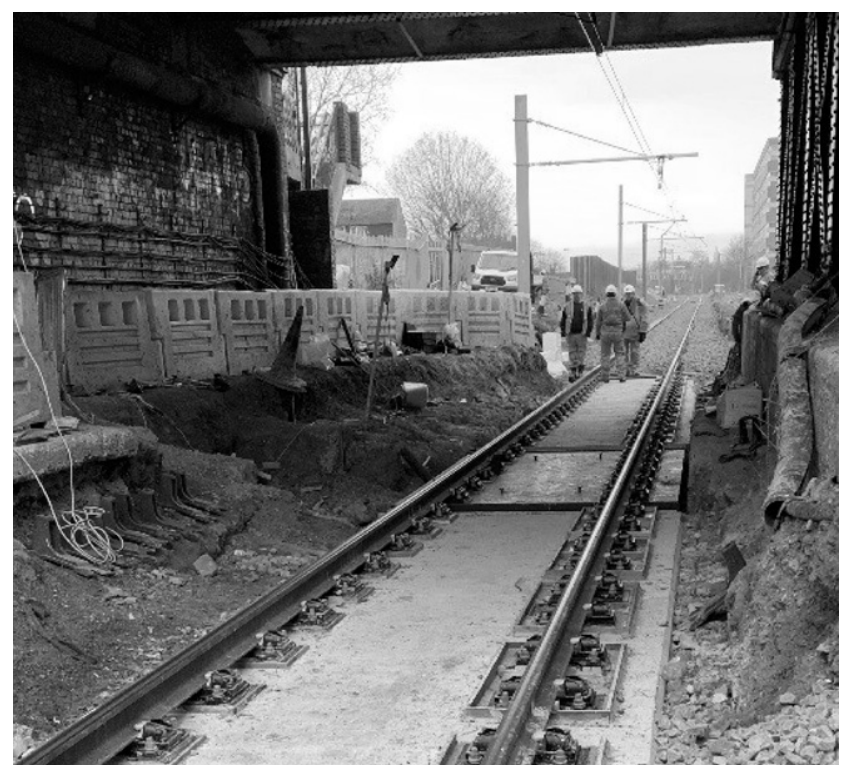

Figure 17. U/B 1395A - view of track slab and steel deck looking south

strains would all be within acceptable limits. Predicted settlements and rotations for the bridge foundations were also found to be acceptable. The results of the potential damage assessment were used to inform the monitoring regime and set trigger values (red, amber, green) in the emergency preparedness plan. Monitoring of the LU track gauge and tunnel lining was undertaken to check and verify that that gauge clearances were not being compromised, while at the surface, the track gauges of the existing up/down Cambridge lines and Ferry Lane overbridge deck and piers were also monitored for movement during construction.

\section{Station structures}

From a geotechnical perspective the station improvement works at both Tottenham Hale and Northumberland Park mainly involved construction of footbridges, staircase links to footbridges, shafts and platform widening (see Figures 18 and 19). For the platform widening and extension, the structural form involved cross wall construction at Northumberland Park station and both front and cross wall construction at Tottenham Hale station for which shallow foundations were adequate in the made ground and/or Enfield Silt. The staircases and footbridges were founded on $450 \mathrm{~mm}$ dia. piles, typically ranging in depth between $7.0 \mathrm{~m}$ and $16 \mathrm{~m}$, depending on

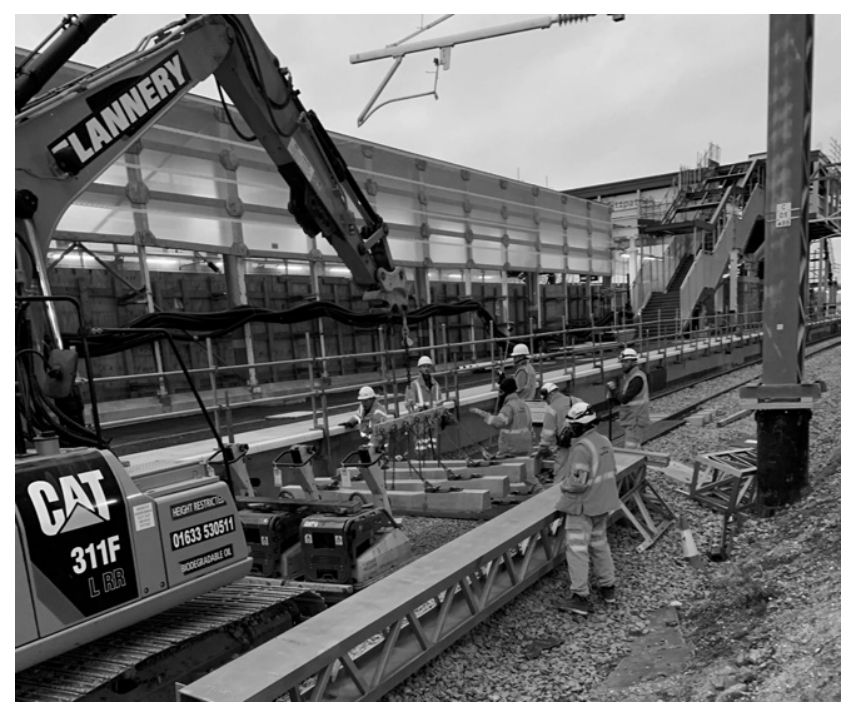

Figure 18. Tottenham Hale station view looking north showing widened platform and new overbridge

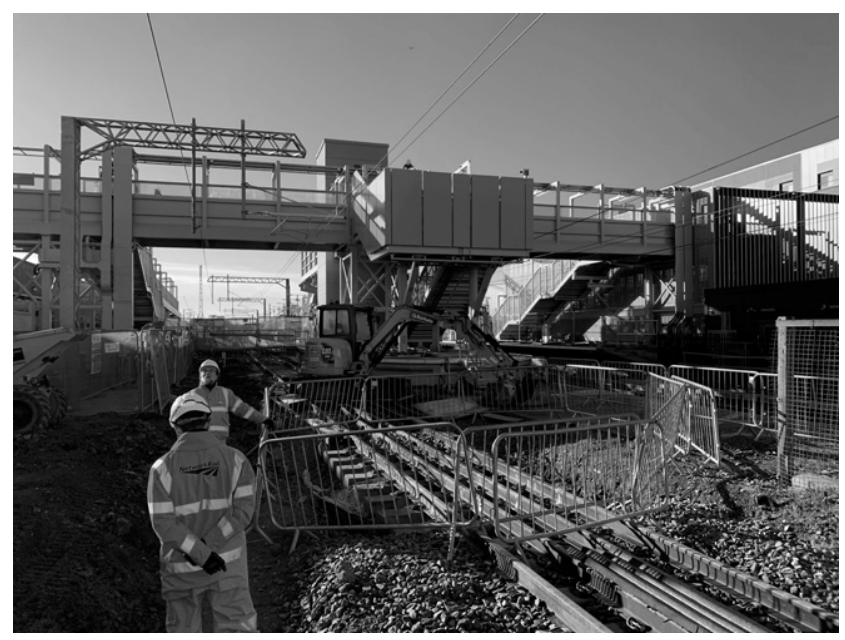

Figure 19. Northumberland Park station view looking north showing new pedestrian bridge and integral lift shafts 
Transport

Volume 173 Issue 4
West Anglia main line upgrade - a

geotechnical perspective

Nyambayo, Chandrashekharaiah, Gray et al. magnitude of loadings, and constructed using a sectional flight auger piling rig. The piles typically penetrated the London Clay, but a few lightly loaded piles terminated in the superficial deposits. Owing to the presence of relatively high groundwater within the superficial terrace gravels, temporary casing keyed into the top of the London Clay was used during boring.

It is notable that although some of the column loadings could be founded on shallow foundations, owing to the plethora of existing and new services the limited available space precluded the use of shallow foundations. Another reason shallow foundations were discounted by the contractor was that it was considered overall to be more time consuming to construct shallow foundations compared to piles, hence this was an unattractive option as it would potentially delay the construction programme.

\section{Overhead line equipment}

The WAML project used the series 2 type of OLE structures (NR, 2011). The design, type and location of the structures made for provisions of the fourth track wherever possible. The structure types included twin track cantilevers, single track cantilevers, dual cantilever, single supported anchors, portals and tie anchors. The major support structures were typically spaced at $50 \mathrm{~m}$ intervals.

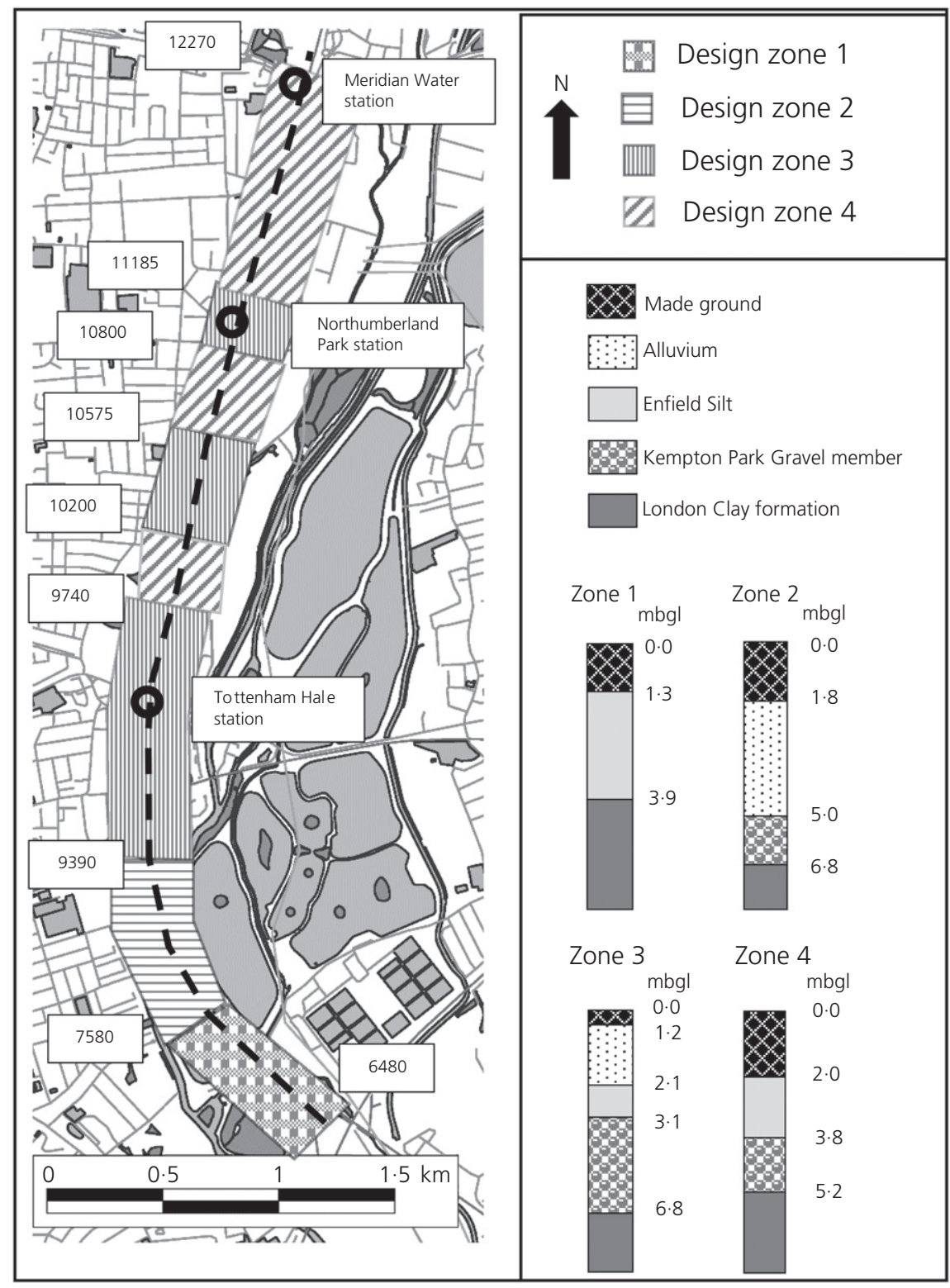

Figure 20. Ground model zones used to design the OLE foundations ( $\mathrm{mbgl}$, metres below ground level) 
Table 3. Summary of geotechnical parameters used for the OLE foundation design

\begin{tabular}{|c|c|c|c|c|}
\hline Strata & $\begin{array}{l}\text { Bulk density, } \gamma: \\
\qquad \mathrm{kN} / \mathrm{m}^{3}\end{array}$ & $\begin{array}{c}\text { Effective angle of } \\
\text { shearing resistance, } \phi^{\prime} \text { : } \\
\text { deg }\end{array}$ & $\begin{array}{c}\text { Effective } \\
\text { cohesion, } c^{\prime}: \mathrm{kPa}\end{array}$ & $\begin{array}{l}\text { Undrained shear } \\
\text { strength, } c_{\mathrm{u}}: \mathrm{kPa}\end{array}$ \\
\hline Made ground & 18 & $27-28$ & 0 & \\
\hline Alluvium & $15-17$ & 21 & 0 & 21 \\
\hline Enfield Silt member & 18 & 23 & 0 & 50 \\
\hline Kempton Park Gravel member & 19 & 36 & 0 & - \\
\hline London Clay formation & 20 & 21 & $0^{\mathrm{a}}$ & $\begin{array}{c}45+10 z^{b} \\
50+7 z^{c} \\
65+4 \cdot 6 z^{d} \\
75+6 \cdot 8 z^{e}\end{array}$ \\
\hline
\end{tabular}

Note: $z$ is measured from the top of the stratum

${ }^{a}$ Route-wide rationalised value

bUndrained shear strength relationship utilised for zone 1

'Undrained shear strength relationship utilised for zone 2

dUndrained shear strength relationship utilised for zone 3

eUndrained shear strength relationship utilised for zone 4

In view of the detailed ground investigation that had been carried out involving $10 \mathrm{~m}$ deep cable percussion boreholes spaced at approximately $100 \mathrm{~m}$ intervals in addition to those carried out at stations and major bridge locations, it was considered that there was good understanding of the ground conditions along the route. From the ground investigations and magnitude of loadings, it was noted that soft ground was present at some locations and in some cases the magnitude of loadings exceeded the threshold specified in Network Rail's design guidance (NR, 2013) for which the office for research and experiments (ORE) standard methodology for OLE pile design (UIC and ORE, 1957) is applicable. From the perspective of design efficiencies, it was deemed more cost-effective to design all the structures using Eurocodes and optimise automation in the design process.

The ground models were rationalised along the route to identify localities with overall similar ground conditions and determine the minimal number of ground models that would optimise the number of design cases to be considered. Figure 20 shows the four ground models (zones) that were identified and their locations along the site. The design ground parameters were derived by considering all the test data (Table 3 ).

Overall, six types of OLE structures and four zones/ground models were developed. For each type of structure there were several load combinations to be considered and analytical spreadsheets developed using Eurocode 7 (BSI, 2004a, 2004b) design principles were used.

By adopting the above approach, and utilising automation in the design software, all the required load combinations were analysed rapidly to determine the pile lengths, which resulted in optimised pile lengths. $610 \mathrm{~mm}$ dia. circular hollow section (CHS) piles were designed and yielded typical pile lengths between $4.0 \mathrm{~m}$ and $7.0 \mathrm{~m}$ long. A general non-effective depth of $1.2 \mathrm{~m}$ was assumed in the analyses to allow for future excavations to install services and this depth was increased where services to specific depths were known. In addition, an upstand of $0.25 \mathrm{~m}$ was included to accommodate the connection to the superstructure. All the foundations were successfully installed with no issues associated with premature refusal in hard ground.

Along the $3.0 \mathrm{~m}$ high Jarrow Road noise bund located just south of Tottenham Hale station, the OLEs were located along the toe of the bund due to limited space within the railway boundary. In order to prevent unduly high lateral loading of the

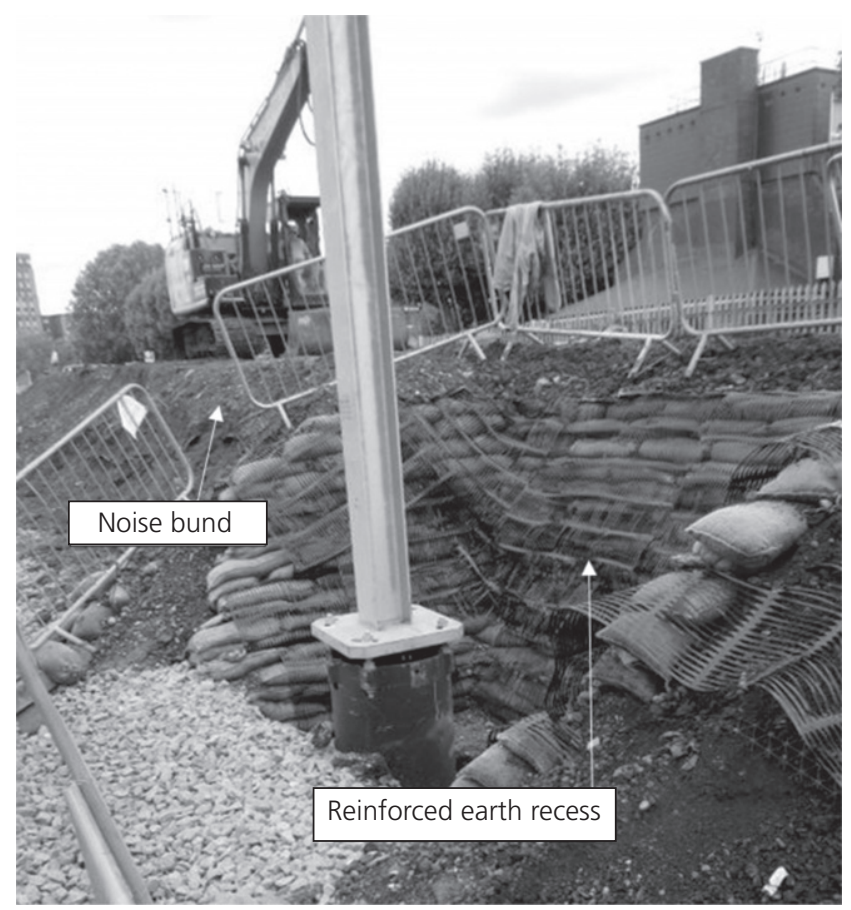

Figure 21. Construction of reinforced earth recess around OLE pile 
bund's slope on the piles, recesses were incorporated around the piles. Owing to the steep angles forming the recesses, reinforced earth was utilised to construct the earthworks (Figure 21).

\section{Conclusions}

London is the economic powerhouse of the UK and a megacity with an ever-increasing population which requires major infrastructure investment projects to be continuously undertaken in order to keep pace with demand. The West Anglia main line upgrade is one such major project implemented in north London to meet the significant increase in current and projected passenger volumes spawned by the successful regeneration of the Elizabeth Park. The project involved the development of a new third track with passive provision of a fourth track within the existing railway servitude and did not involve third-party land lake. Owing to the lack of historical records on ground data, a full ground investigation had to be carried out to inform the design of a new track bed and new substructures.

As is typical of very old cities, the development of new infrastructure generally interacts with old infrastructure whose serviceability and construction details are usually not fully known. Although intrusive investigations can go a long way to ameliorate this hurdle, some gaps often remain which impinge on design of new works. This was the case for the historical bridge BGK1393, where intrusive investigations could not confirm the full geometry of the bridge abutments for them to be reused, hence new abutments had to be designed and constructed. At Ferry Lane Bridge, track lowering under the existing road overbridge required a piled slab track in order to relieve loading on an existing tunnel and large-diameter water mains.

Construction in old stations currently in use also involves interaction with a number of existing services and, for foundation installation, it is usually more efficient to utilise piles as they involve minimal excavations and generally achieve faster installation times, which is beneficial to programme delivery. Although some foundations are lightly loaded and ground conditions could be adequate to support pad foundations, the timescales involved in installing pad foundations and limited availability of time during track possessions generally renders them unattractive from a programme and cost perspective.

\section{Acknowledgements}

The authors would like to acknowledge the valuable contribution of Mr Adrian Pettigrew (Volker Fitzpatrick Limited) in the production of this paper and are also grateful to Network Rail and VolkerFitzpatrick for granting permission to publish the paper.

\section{REFERENCES}

BGS (British Geological Survey) (2006) North London, England and Wales Sheet 256, Bedrock and Superficial Deposits 1:50 000. BGS, Keyworth, UK.
BRB (British Railways Board) (1963) The Reshaping of British Railways, Part 1. HMSO, London, UK.

BSI (2003) BS EN 1991-2: Eurocode 1: Actions on structures - Part 2: traffic loads on bridges. BSI, London, UK.

BSI (2004a) BS EN 1997-1: Eurocode 7: Geotechnical design. Part 1: general rules. BSI, London, UK.

BSI (2004b) BS EN 1997-2: Eurocode 7: Geotechnical design. Part 2: ground investigation and testing. BSI, London, UK.

EBC (Enfield Borough Council) (2019) See https://www.meridianwater. co.uk (accessed 20/09/2019).

HA (Highways Agency) (2016) Manual of Contract Documents for Highway Works, Vol 1, Specification for Highway Works, Series 600. The Stationery Office, London, UK.

NR (Network Rail) (2005) NR/SP/TRK/9039: Formation Treatments, Issue 1. Network Rail, Milton Keynes, UK.

NR (2011) Specification 'Series 2 OLE Design System Description Manual'. Network Rail, Milton Keynes, UK, Document No. 118335/11.06/Series 2/61259122.

NR (2013) PAN/E\&P/EE/CS/101: Guidance on Design of Foundations for Overhead Line Structures. Network Rail, Milton Keynes, UK, Project Advice Note.

NR (2017) NR/L2/INI/P3M/101: Governance for Railway Investment Projects (GRIP) - Projects. Network Rail, Milton Keynes, UK.

Nyambayo V, Simoes Coelho R and Asare M (2019) Overcoming design challenges for an urban railway interacting with fragile 19th century infrastructure in London, UK. In Proceedings of the 17 European Conference on Soil Mechancis and Geotechnical Engineering (ECSMGE-2019): Geotechnical Engineering, Foundation of the Future (Sigursteinsson H, Erlingsson S and Bessason B (eds)). The Icelandic Geotechnical Society, Reykjavik, Iceland, https://doi.org/10.32075/17ECSMGE-2019-0059.

ONS (Office of National Statistics) (2019) See https://www.gov. $\mathrm{uk} /$ government/organisations/office-for-national-statistics (accessed 04/11/2019).

Randolph MF (1977) A Theoretical Study of the Performance of Piles. $\mathrm{PhD}$ thesis, University of Cambridge, Cambridge, UK.

RC (Railway Codes) (2019) Engineer's line references. See http://www. railwaycodes.org.uk/elrs/elr0.shtm (accessed 04/11/2019).

TRL (Transportation Research Laboratory) (2004) Dynamic Cone Penetrometer Tests and Analysis. TRL, Crowthorne, UK, Project report PR/INT/277/04.

UIC and ORE (International Union of Railways and Office for Research and Experiments) (1957) Calculation of Catenary Masts and Foundations. UIC and ORE, Paris, France and Ultrecht, the Netherlands, A 1a/RP1/E.

\section{How can you contribute?}

To discuss this paper, please email up to 500 words to the editor at journals@ice.org.uk. Your contribution will be forwarded to the author(s) for a reply and, if considered appropriate by the editorial board, it will be published as discussion in a future issue of the journal.

Proceedings journals rely entirely on contributions from the civil engineering profession (and allied disciplines). Information about how to submit your paper online is available at www.icevirtuallibrary.com/page/authors, where you will also find detailed author guidelines. 